\title{
Alexander Collie: The Ups and Downs of Trading with the Confederacy
}

\section{Michael Clark}

\begin{abstract}
Au mois de mars 1861, Lincoln a annoncé un blocus naval pour empêcher le commerce entre l'Europe et les États confédérés séparatistes. Ceci a présenté un moyen pour les spéculateurs de bénéficier de la fourniture à la Confédératon de marchandises et d'armes échangées contre le coton. Parmis les plus actifs l'on trouve Alexander Collie, un négociant basé à Londres et agent pour l'état de la Caroline du Nord et pour les organismes gouvernementaux confédérés. La défaite de la Confédératon en 1864, a provoqué sa faillite avec un passif de £3 million. Dans un but de réunir cette somme, il a frauduleusement circulé des lettres de change fausses d'une valeur de $£ 1.75$ million, mais avant son procès en 1875, Collie s'est enfuit.
\end{abstract}

\section{Part One}

\section{Beating the Blockade}

Within a few months of the start of the Civil War, the United States commanded the sea along the Confederacy's 3,500 miles of coastline from Virginia to Texas, despite having a navy of fewer than fifty warships. ${ }^{1}$ The effect of the blockade on the trade of the Confederate States was critical and it encouraged an influx of speculators, most of whom were British. It cost the Confederacy about two dollars to receive one dollar's worth of goods and it was paid very little of the vastly inflated price of its cotton and pine-resin sold in Europe. ${ }^{2}$ In a House of Commons debate in March 1862, a prominent shipowner, maritime author and outspoken advocate for the Confederacy, William Schaw Lindsay MP, described the blockade as "an infinitely stronger interference with private interests and private property than the right of capture at sea." 3 The United States answered that the blockade was a war measure aimed only at the states in rebellion.

1 Richard Lester, "Procurement of Confederate blockade runners and other vessels in Great Britain during the American Civil War," Mariner's Mirror 61 (August 1975), 75

2 Hamilton Cochran, Blockade Runners of the Confederacy (Indianapolis: Bobbs-Merrill, 1958), 173.

3 The Scotsman (Edinburgh), 17 March 1862.

The Northern Mariner/le marin du nord, XIX No. 2, (April 2009), 125-148 
The Confederate government was reluctant to interfere in the economies of its states but it proposed an embargo on cotton exports to create an artificial scarcity in the hope that it would encourage foreign recognition. The governor of North Carolina, Zebulon Vance, though, believed the value of his state's cotton was the equivalent of gold in England and decided to control the ships that carried it to generate hard currency to purchase war supplies and food for the poor "without taxing the people a dollar." In July 1862, North Carolina appointed Alexander Collie and Company as an agent in London to handle the state's commercial affairs. Alexander Collie was born in Aberdeen in 1824, where his father George was a merchant. On 12 April 1860, Alexander, described as a commission agent, married Irish-born Flora Jane Macneill, a descendent of Flora MacDonald, in Edinburgh. ${ }^{5}$ His younger brother William was the nominal head of the Manchester office.

Although the official records of Alexander Collie and Co. have been lost, several wealthy Lancashire investors were informally involved financially including the selfdescribed adventurous investor Lord Wharncliffe. ${ }^{6}$ In August 1862, he founded the Southern Independence Association to co-ordinate donations to purchase and transport materials to the Confederacy and chaired the Committee for Relief of Southern Prisoners of War as a humane way of demonstrating sympathy without political involvement. He was also reputed to have organised a bazaar to sell goods for the relief of Maryland without realising that the state remained in the Union. Another partner was James Spence, a Liverpool iron merchant, banker, stockbroker and financial agent for the Confederacy in Europe. He confidently asserted to Wharncliffe that their returns would easily outweigh the risks since the Confederacy was not only standing firm but looked to be the probable victor. ${ }^{7}$

Trading with the Confederacy was just one of Alexander Collie's many speculative ventures: he had so many that he referred to them by number. ${ }^{8}$ Early in 1862 , he entered into a formal contract with John White, a special commissioner for North Carolina in Britain. Notwithstanding White being a merchant of wide experience, Collie took control of every aspect of the contract and he received and paid for all European purchases made by the state and acted as consignee for all its cotton shipped to Britain. It was a complicated and expensive operation but every transaction earned Collie a commission or a fifty percent mark-up.

When White failed to agree commission levels demanded by the French

4 Michael L. Weisel, "Dixie Gentlemanly Capitalism: Studies in British Finance and the Confederacy" (MA thesis, University of North Carolina, 2003), 49. This work is especially valuable because of its extensive use of the excellent collections at the North Carolina State Archives, Raleigh, NC.

5 In St. John's Episcopal Church. 1861 Census: Collie and seven servants lived at Irwell House, Prestwich, Lancs.

6 Sheffield City Library Archives, Wharncliffe Manuscripts, microfilm (see www.microform.co.uk/guides/R03542.pdf).

7 Ibid., Spence to Wharncliffe, item no. 5, 3 January 1864, and no. 6, 5 January 1864.

8 Ibid., List of vessels engaged in Collie's ventures, item no. 4. 
merchant bank Émile Erlanger to market a cotton-based loan with state issued Confederate Cotton Bonds, he turned to Collie. ${ }^{9}$ The warrants, also called cotton certificates, were denominated in value at $£ 100$ and guaranteed redemption against twelve $400 \mathrm{lbs}$ bales of cotton. Carrying interest at seven percent per annum until delivery of the cotton, they entitled a purchaser to specific payments at regular intervals. With a minimum notice of sixty days, cotton would be available to warrant holders at Wilmington, Charleston or Savannah or any other port in the possession of the Confederate government. If the cotton was not claimed within three months after the ratification of a peace treaty with the United States, the certificates could be exchanged for North Carolina State Bonds carrying eight percent interest per annum. As a financial instrument they were particularly attractive to speculators as collateral in a fluctuating cotton market. Collie sold many warrants to his associates, promising that he would be personally responsible for their redemption by the state and he assured sceptics that even if the Confederacy perished, the Union would guarantee its foreign debts. Each sale earned Collie a commission of five percent net of solicitor's fees and bank charges.

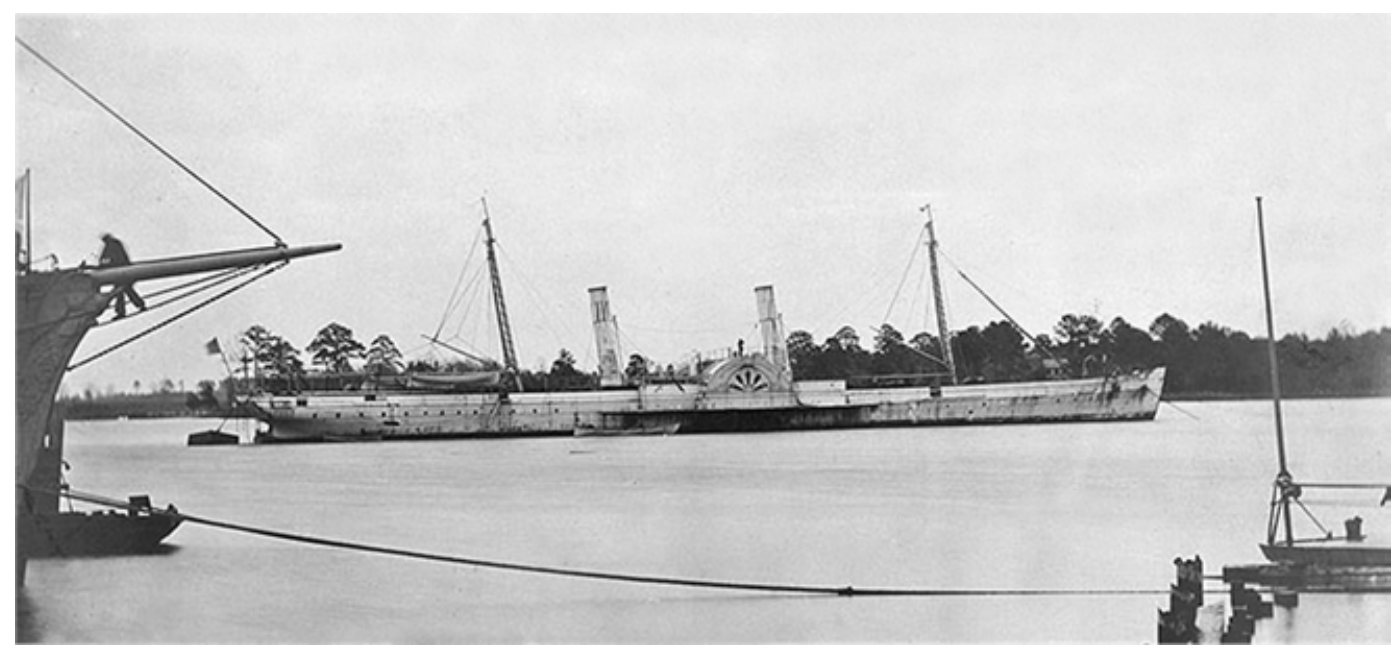

Fig. 1: USS Fort Donelson, ex-Giraffe in port, circa 1864-65. Author - public domain.

In Britain, the economic impact of the Civil War stimulated heavy industry. The contracts made for blockade running steamers for what was called the Nassau trade featured a good deal of obfuscation to disguise the identity of buyers. Alexander Collie purchased one of the first vessels on the River Clyde, the paddle-steamer Giraffe. On 10 October 1862, the ship was moored in Todd and McGregor's yard at Glasgow and Captain Wilkinson, whose orders came directly from the Confederate Secretary of War, James Seddon, converted it for the transatlantic run. ${ }^{10}$ Collie transferred title to the Confederate government for $£ 32,000$ on condition that the ship should not be sold during the war without his consent or first refusal. Its registration was transferred to a Liverpool

9 Weisel, 51. The Erlanger Loan was marketed by London shipbrokers W. S. Lindsay, Edgar Stringer and Edward Pembroke.

10 Glasgow University Archive Services Collections, Todd and McGregor, shipbuilders, Glasgow, [list of vessels built], UGD 239/1 (see www.gla.ac.uk/media —60666.en.pdf). 
speculator, immediately re-sold to Collie's occasional partner, London shipbroker Edward Pembroke, and renamed Robert E. Lee. ${ }^{11}$ Wilkinson bought arms, clothing and munitions through Collie and booked the passengers, including twenty-six Scottish lithographers engaged to design and print Confederate paper money. The vessel slipped past the United States Navy warship blockading the Carolina coast, only to run aground briefly just outside the bar. After fourteen successful runs, it surrendered to a Federal gunboat in the blockading squadron in November 1863 while en route to Wilmington. In more ways than one, it was a valuable prize. A letter was found on board, dated Manchester 14 November 1862, addressed to Wilkinson and signed Alexander Collie and Brother. It offered to supply the Confederate Navy and Army with further boats and products and to dispose of any cotton that the Confederate government brought to Britain. $^{12}$

The close of 1862 saw growing criticism of the Confederate government for doing too little to manage its own financial affairs. William Crenshaw, a wealthy textile merchant and owner of import/export businesses in Richmond, Virginia was sent to Britain by Seddon. He was to form a partnership with a company to purchase new blockade runners secured against a promise of cotton at a price that would ensure the state an enormous profit. Not surprisingly, Crenshaw chose Alexander Collie. They agreed that the Confederate War Department and the Commissary and Quartermaster's Bureaux would meet seventy-five percent of the cost of the ships, with Crenshaw and Collie covering the remaining twenty-five percent. In addition, Collie would take charge of one-and-a-half million Federal dollars worth of cotton bonds drawn on the state of North Carolina. ${ }^{13}$ Edward Pembroke paid $£ 46,000$ in cash to George Thomson, owner of the largest shipyard on the upper Clyde, to build a warship larger and more powerful than the Liverpool-built cruiser Alabama. Pembroke subsequently transferred ownership to Lieutenant George Sinclair of the Confederate States Navy in exchange for 245 cotton bonds worth $£ 51,250$ redeemable at a Confederate port. Collie earned a commission on both transactions. ${ }^{14}$

Alexander Collie now part-owned or controlled a mixed fleet of sixteen steamers and he raised $£ 2$ million capital by public subscription to form a mutual association to undertake war-risks insurance on his ships and cargoes. Throughout 1863, the vessels carried quartermaster and medical stores for the Confederate government to Bermuda and returned with cotton for Collie's own account, either exchanged for merchandise taken in, or bought by his agents with money derived from his share of the sale of other, often

11 Eric J. Graham, Clyde Built (Edinburgh: Berlinn, 2006), 50. Pembroke fronted Scottish-born runner Thomas S. Begbie.

12 Official Record of the Union and Confederate Navies in the War of the Rebellion, series I, vol. 9 (Washington: Government Printing Office, 1899) [hereafter ORN], 286, Collie and Brother to Wilkinson, 14 November 1862.

13 Thomas Boaz, Guns for Cotton: England Arms the Confederacy (Shippensburg,PA: Burd Street Press, 1996), 49. Unless otherwise stated, references to dollars are U.S. Federal dollars and calculated at an exchange rate of US5.00 to $£ 1$.

14 Graham, 133. 
luxury, goods in the Confederacy. ${ }^{15}$

By the spring of 1863 , running the blockade had almost become an industry and Alexander Collie was fully entrenched in the affairs of the Confederacy. At monthly intervals during the summer, Crenshaw and Collie's joint venture launched three fast steamers at a cost of $£ 14,000$ each. Crenshaw then bought the building contract for the twin-screw steamer Hebe from Collie, earning each principal one percent brokerage and 2.5 percent commission on all the deals. ${ }^{16}$ In the meantime, Collie sold $£ 99,900$ worth of cotton warrants delivered to him by White in payment for goods already shipped to North Carolina. Part of this equity was used by Collie as leverage to float a loan of $£ 35,000$ from his own company on behalf of North Carolina to buy the Greenock-built iron paddle-steamer Lord Clyde for $£ 32,000 .{ }^{17}$ The remainder established a line of credit for White to purchase railway iron, rolling-stock and 250 tons of assorted war materiel with the state's money. Collie personally supplied 50,000 grey blankets to the state, no doubt paid from the commissions from transactions incurred in his role as its purchasing agent. Within a month, the fully laden Lord Clyde, renamed Advance, was on its way to Bermuda and, after five round trips, Vance sold North Carolina's half interest for $\$ 35,000$, about $£ 7,000 .^{18}$

The paddle-steamer Flora was built for the Bristol General Steam Navigation Co. by Scott \& Co. of Greenock in 1858. The yard's records show that in 1863, it was bought by W. S. Lindsay and Co. for $£ 35,000$, although it is not clear why Scott was still interested in a vessel five years after it left the yard. ${ }^{19}$ It is more likely that Lindsay was merely the broker for the sale and this is partly borne out by an American consular dispatch from Bristol, dated 23 July $1863 .{ }^{20}$ It reported that Flora, as was the case with Juno and Calypso, was "fitted out by the infamous W. S. Lindsay of parliamentary and shipping notoriety or his shipping firm. ${ }^{21} \ldots$ Flora was sold for $£ 35,000$, some $£ 3,000$ more than it cost new [and] is said to be the fastest running steamer in the British (sic) Channel. ${ }^{, 22}$ In fact this trio of ships was running for Alexander Collie.

After the banker Henry Schroder and Collie each contributed $£ 50$ to erect a statue of Confederate General Jackson in Manchester, the British press referred to Collie as a

15 Frank Vandiver, Confederate Blockade Running through Bermuda 1861-1865 (1947; repr., New York: Kraus, 1970), 42, 44, 47, 51: John Bourne's disbursement accounts, reshipment bills and charter party to A. Collie and Co.

16 Stephen Wise, Lifeline of the Confederacy: Blockade Running During Civil War (Columbia, SC: University of South Carolina Press, 1988), 102.

17 Cochran, 101.

18 Weisel, 53.

19 Johnson Robb "Scotts of Greenock 1820-1920: A Family Enterprise" (PhD thesis, University of Glasgow, 1993), II: 174. It is not clear why Scotts were interested in a ship five years after leaving its yard.

20 The Times (London), 26 January 1863.

21 My italics.

22 ORN, series 1, 9: 153. 
leading blockade runner. He had certainly become a major shipper of merchandise to the Confederacy and he profited from lucrative War Department contracts that employed the new and larger steamers. When one vessel carried an excess of coal on its maiden voyage, Collie apologised to Seddon that it had not earned as much freight as expected. During the third quarter of 1863, Collie ran out one million Federal dollars' worth of $\operatorname{cotton}^{23}$ and a six-month sales account for cotton shipped on Advance alone showed a net credit to the state of $£ 9,163 .{ }^{24}$ In contrast, Crenshaw's purchasing debts had grown to over $£ 115,000$ and he was forced to sell the Venus to Collie to pay his creditors. ${ }^{25}$

Alexander Collie began to face strong competition from new sources willing to supply North Carolina for a twenty percent profit on goods and ten percent on cotton. ${ }^{26}$ Crenshaw supported Collie by telling Vance that he "had done more than I had a right to expect." ${ }^{27}$ However, Collie had become disillusioned with Crenshaw, and blamed his bad management of the joint venture for the loss of Venus and that his "nasty jealous spirit" was creating hostility among other shippers. ${ }^{28}$

Collie contacted John White again in October 1863, claiming that the time was now ripe to supply North Carolina with its chief commercial requirement of railway iron and rolling-stock. ${ }^{29}$ To achieve this efficiently, Collie proposed to furnish the state with four of the most suitable steamers for blockade running. A quarter-interest in each vessel would belong to North Carolina with three-quarters owned by Collie and his partners, although the entire capacity on the westbound leg from Britain could be available to the state at a low freight rate to be agreed later. Collie undertook to run out a regular quantity of cotton to enable North Carolina to benefit from the high prices available in Europe and the state would be entitled to one-quarter of the space in each vessel for cotton or other produce. He claimed this would not only generate more than enough to cover the state's costs, but that the charges on the inward leg of each voyage, together with cash from its share of outward cargo, would generate a large surplus. If there was insufficient cargo for North Carolina, Collie would find other shipments and credit the state with a share of any freight. He concluded, without any hint of irony, that the details of the agreement could be left to the good faith and honour of the partners and any proposals for altering the conditions should be considered by the governor "in the same liberal spirit that he asked them to place in him." ${ }^{30}$

23 Cochran, 136.

24 North Carolina State Archives, Treasurer and Comptroller Records, Military Papers, Box 95, 1864.

25 Serge Noirsain, "The Blockade Runners of the Confederate Government, Part 1," 10 [Confederate Historical Association of Belgium] http://chab-belgium.com/pdf/english/ Blockade\%20Runners 1.pdf.

Wise, 136-7.

Weisel, 53.

Ibid. 
Given the success of Collie's ships in breaching the blockade, his proposal proved irresistible to White. The agreement they signed on 27 October 1863, however, had become rather one-sided in Collie's favour. It now read that Collie would furnish four steamers of suitable construction and speed as soon as practicable.$^{31}$ North Carolina would pay for its share of the cost of outfitting the ships and purchases made abroad by cotton-warrants at par. To make good the warrants, the state should purchase and keep in trust for the holders 11,000 bales of cotton and 100,000 barrels of rosin. ${ }^{32}$ Working expenses would be shared pro-rata and if the partners decided to sell any vessel, the net proceeds or any freight would be credited in like proportion.

On his part, Collie would hand over Hansa and Don to North Carolina on their next voyages at a price of $£ 20,000$ for a quarter interest in each ship, which he claimed was under market value. He would deliver 1,000 tons of railway iron and rolling-stock at a freight rate of $\$ 5.00$ per ton payable in advance, one-quarter of which would be credited to the state as its interest. For any other cargo, the rate would be $\$ 30.00$ per ton. The state would still own one-quarter capacity on the eastbound voyage but there was no limit on the amount of cotton or other produce that Collie's agents could purchase and transport from the interior. On arrival in Britain, one-quarter of the proceeds would be credited to the state, less charges for transshipment and storage at the loading port, brokerage of 2.5 percent on purchases and a commission of five percent on disbursements. The state's share of cotton would avoid the buying commission of 2.5 percent but, if Collie took cash advances for the state rather than putting cotton-warrants in the market, he would receive double the commission plus interest of five percent. Good faith and honour indeed.

Collie's luck began to change in November 1863. In a short period, he not only lost Hebe and Venus, but Ceres was captured and Hansa only escaped from a Federal steamer by throwing its deck-load of cotton overboard to lighten the ship. The market for steamers designed to run the blockade was becoming over-supplied. On the Clyde alone, forty-two suitable deep-sea vessels, many intended for Collie, were under construction in twenty-seven shipyards. When added to the sixty-four vessels already sold, the investment amounted to almost $£ 1.5$ million. ${ }^{33}$

In a speech in 1885 , Governor Vance claimed that out of 2,054 attempts to run the blockade on the Atlantic seaboard 1,735 succeeded and in the Gulf, of 2,960 attempts, about 1,900 slipped through. ${ }^{34}$ In other words, there was respectively an 84 to 65 percent chance of avoiding the United States Navy's patrols. Vance also claimed that North Carolina imported sixty percent of its small arms by sea, together with thirty percent of its lead, seventy-five percent of its saltpetre and nearly all its paper for making cartridges. The state had collected and distributed so much military supplies that a significant quantity was turned over to the Confederate government for the troops of other states.

\footnotetext{
31 My italics.

32 Weisel, 56.

33 The Dumbarton Herald, 27 April 1864.

34 Weisel, 56. The number of successful runs were later proved to be higher.
} 
A new and difficult situation arose for Collie at the beginning of 1864. The Confederate government announced that one-third of all cargo capacity in privately owned vessels would be allocated to it against a commensurate freight payment that was (in the view of the Confederate government) reasonable. Vance replied that not only did his arrangement with Collie for shared ownership exempt North Carolina from this new edict, but their vessels had been very successful in evading the blockade. The agreement with Collie was valid until the steamers were sold, captured, or destroyed and no important steps, such as disposing or replacing vessels, could be taken without the full knowledge and consent of the partners. Since the Confederacy now had no ships and very little money abroad, Vance felt he should be free to relieve his troops and people with his own vessels. ${ }^{35}$

It was left to Seddon to concede that North Carolina could continue its cooperation with Collie and, by March 1864, the state commandeered one-half of all the available cargo space. ${ }^{36}$ Collie suggested to White that, to spread the risk of capture, North Carolina should now divide its interest over even more vessels and offered to supply two new screw-steamers similar to Ceres. As a result, the first half of 1864 saw the joint-venture ships make fifty trips into Wilmington with supplies and munitions, returning to Britain with cotton. Citing economy and efficiency, Collie insisted that the day-to-day management of the ships, including appointing captains and officers, remained in his hands. ${ }^{37} \mathrm{He}$ presented North Carolina with the latest Whitworth gun and ammunition, to be positioned at Fort Fisher, which was commanded by Colonel William Lamb. The gun was not only pivotal to the defence of Wilmington but it also facilitated the entry of Collie's steamers to the port by repelling any pursuing United States naval vessels and forcing the blockading fleet to move its anchorage from two miles to five from the fort. ${ }^{38}$ Collie wrote enigmatically to Vance:

I have shipped on board the Edith a new kind of gun, which is reported to be particularly destructive; and I have to ask the authorities at Wilmington to accept it as a "substitute" for some of our people, who, but for our business, would have been doing business in another capacity. ${ }^{39}$

The idea of the gift may have come from Crenshaw as he had given a battery of three field guns to Virginia but it also seems to have been a bribe to exempt his local employees from conscription to the Confederate Army. In Wilmington, Collie employed "quite a regiment of youngsters - fine looking fellows with turned-up noses." ${ }^{\text {" Known }}$

35 Weisel, 55.

36 The War of the Rebellion: A Compilation of the Official Records of Union and Confederate Armies, series 4, vol. 3 (Washington: Government Printing Office, 1900)[hereafter, ORA], 187-9, Memminger and Seddon, "Official Regulations upon... Foreign Commerce," approved by Jefferson Davis, 5 March 1864.

37 These were often experienced British naval officers sailing under assumed names.

38 Jim McNeil, Masters of the Shoals (Cambridge, MA: Da Capo, 2003), 19.

39 U.S. Supreme Court. Young v. US, 97 U.S. 39 (1877) 15

40 John Jones, “Wilmington During Blockade," Harper's Monthly Magazine 32, no. 196 
as the English Sybarites, they were lodged in a hospital-like boarding house which acquired a reputation of "sin and degradation with constant parties and visits by prostitutes - the scandal of the town. ${ }^{.41}$ Collie presented two more Whitworth guns for the Confederacy's field service, but these gifts were to cost him dear in an unexpected way.

On 13 June 1864, Alexander Collie entered into a contract with Colin McRae, the Confederate financial agent in Europe ${ }^{42}$ It was intended to be similar to that agreed with White and the terms were to be construed in a spirit of confidence and liberality. In reality, this contract was even more favourable to Collie. McRae would cover the cost of Collie's agencies in the Confederacy and his employees could reside there free from liability to conscription. Collie undertook to promptly provide the Confederacy with four new large and powerful steamers and to purchase and to ship quartermaster's stores to the value of $£ 150,000$ and ordnance or medical supplies to the value of $£ 50,000$ over a sixmonth period. The goods would be taken over by the Confederacy immediately on arrival and a fifty percent advance added to Collie's invoice on delivery plus a commission of 2.5 percent. $^{43}$

In return, Collie would be paid with full ship-loads of "middling"quality cotton, supplied through his agent in North Carolina and promptly delivered to his steamers in proportionate quantities. The cotton would be in good merchantable condition, compressed, packed and free from all charges beyond the existing export tax of $1 / 8$ of 1 cent per pound. Collie would charge inland carriage and packing expenses in addition to his 2.5 percent commission. Neither party would withhold supplies due to temporary shortcomings on the part of the other. Collie's steamers would have priority over all others and more than the four named vessels could be used if he could supply them. $\mathrm{He}$ was free to provide and ship other cotton, or even tobacco, up to one-tenth of the vessel's cargo-space on the same terms as the government's cotton. It was hardly surprising Collie boasted that, at the agreed price of six-pence sterling per pound weight, the contract would earn him a gross profit of $£ 800,000$ once the cotton was sold in Liverpool. ${ }^{44}$ Indeed, an agreement of confidence and liberality.

To fulfil his contract with McRae, Collie ordered five technically advanced paddle-steamers on the Clyde, each designed to carry 1,000 bales of cotton. However, Collie's optimism declined as, one by one, they suffered mechanical problems and made no runs during a critical period of the war from November to December 1864. Worse still, several of his vessels had been captured by the United States Navy during 1864. Showing his frustration, Collie wrote to Wharncliffe apropos Secretary of State Seward, "what can be expected of a pig but a grunt?" 45 As his situation deteriorated, Collie asked Wharncliffe if he thought it likely that the South would be recognised in the next session

(September 1866): 499.

41 Wise, 106, 129.

42 ORA, series 4, 3: 529-530, memorandum of agreement Collie and McRae, 13 June 1864.

43 Ibid.

44 Wise, 149-151.

45 Wharncliffe Manuscripts, Collie to Wharncliffe, 2 January 1865, item no.14. 
of Parliament. ${ }^{46}$

The Richmond Daily Dispatch described Collie as a liberal citizen of London when he donated $\$ 10,000$ to Seddon "to the aid and assistance of the soldier's families and others in the Confederacy reduced to want by the war." ${ }^{27}$ Apparently for selfpromotion, Collie requested the newspaper to publish a letter from Seddon to the chairman of the Army Committee of the YMCA in Richmond, in which he asked that one third of the money, $\$ 3,333,33$, be drawn upon William Collie at Wilmington "f8 "for the relief of the poor under the charge of your excellent association." ${ }^{49}$ Other evidence that William was working in North Carolina, and now making a hasty departure, is contained in a letter from Vance to White in London written five months later. Reporting the capture of Wilmington and the suspension of North Carolina's blockade running operation, it was being carried by William Collie "who will give you the military news." 50

The capture of Fort Fisher on 15 January 1865 closed the port of Wilmington. The Trans-Mississippi Department of the Confederate Army needed at least 14,000 stands of arms for the troops in the field, while the unarmed reserve corps could use 25,000. ${ }^{51}$ There were many government-owned Enfield rifles in the West Indies under Collie's contract with the Confederate government, but he no longer had ships to deliver them. Nor could he load his 4,936 bales of upland and sea-island cotton lying on the quay at Savannah. As ship values slumped, Collie took delivery of four of the new steamers. That these vessels were Confederate government property liable to be seized by United States financial agents illustrates how rapidly he abandoned his former partner. Collie failed to persuade the Admiralty to buy all four as fast patrol boats but in the months that followed, he sold two to buyers in the River Plate at a loss of $£ 18,000$ on each ship and they later bought the other two at an undisclosed price. ${ }^{52}$ Running the blockade had made Alexander Collie a fortune but the outcome of the war had caught him by surprise.

\section{Part Two}

\section{Facing Bankruptcy}

In the space of two years, Alexander Collie and his family had risen from living in a Georgian house in the industrial city of Manchester in 1861, to a villa in Sussex Gardens in the respectable London suburb of Bayswater. At the beginning of 1863, he paid $£ 25,000$ for a mansion at 12 Kensington Palace Gardens, still today London’s most

46 Ibid., Collie to Wharncliffe, 23 January 1865, item no. 27.

47 Richmond Daily Despatch, 10 October 1864. It is not clear in which currency Collie made this donation but it is most likely to have been Confederate States dollars.

48 My italics.

49 Richmond Daily Despatch, 10 October 1864.

50 ORA, series 4, 3: 1117, Vance to White, 28 February 1865.

51 ORA, series 1, vol. 48, pt. 1 (Washington: Government Printing Office, 1896), 1319, Smith to Gorgas, 8 January 1865.

52

Wise, 224. 
expensive residential area, and managed to spend several thousand pounds improving it. ${ }^{53}$ John Norman Collie, Alexander's nephew, later claimed that the family wealth had been made in the cotton trade but that the outcome of the Civil War resulted in their financial ruin after Alexander Collie and Co. had failed because of an insurance scam. The cause of Alexander Collie's financial disaster was very different.

By April 1865, Collie accepted that his fortune seemed lost. As one of the Confederacy's major trading partners, he had over-extended by investing in new ships and North Carolina $£ 100$ cotton bonds. He held a nominal $£ 20,000$ worth, but a list of other prominent holders of the now worthless bonds who had links to Collie was headed by Thomas Begbie with $£ 140,000$ worth, followed by James Spence with $£ 50,000$. William S. Lindsay and Lord Wharncliffe each held $£ 20,000$. The estimated total was $£ 898,500 .{ }^{54}$ United States consuls were said to be ready to seize Collie's remaining ships as the property of the now defunct Confederate States of America and Collie wrote to Wharncliffe about pre-empting this by selling them himself. ${ }^{55}$ As Collie searched around for new funds, he presented a bill for $£ 30,000$ to Peter Tait, a Shetland-born, Irish military clothing contractor. This represented Tait's share of alleged losses in a joint venture in December 1863 when Tait had supplied Seddon with $£ 150,000$ worth of clothing. Tait rejected the bill, claiming that Collie had repeatedly cheated him by hiding profits and sales accounts. Surprisingly, the two continued to do business together. Tait made a substantial investment in a shipping company with Collie, but the venture failed and contributed to Tait's eventual bankruptcy. The evidence is inferential but it appears that Tait had once again been cheated. ${ }^{56}$

Collie's allegation that 16,000 bales of his cotton were stored at Savannah in December 1864 when the city was captured by the United States Army must be treated with suspicion. ${ }^{57}$ Perhaps he hoped to fraudulently hedge on the cotton, but it had already been seized by the army, shipped to New York and sold. The proceeds, amounting to US\$950,076.71, were paid into the United States Treasury. In February 1866, some shareholders in Alexander Collie and Company complained about the running of the company. Collie confirmed to Wharncliffe that it was effectively bankrupt and would soon have to close its books, although it didn't cease trading until 27 June $1868 .{ }^{58}$ Collie continued to put together opportunistic deals to raise money. When the British government created a telegraph monopoly in 1867 , he contrived to sell it the rights of the defunct Bonelli's Electric Telegraph Co. Its directors had been willing to accept $£ 5,000$ but Collie challenged the valuation and obtained $£ 22,000$ from the Post Office, receiving

53 Edward Walford, Old London: Belgravia, Chelsea and Kensington (London: Village Press, 1989).

54 "How British Money was Lost in the South," The Times (New York), 14 May 1915.

55 Wharncliffe Manuscripts, Collie to Wharncliffe, items no.59, 3 April 1865, and no. 60, 7 April 1865.

56 John Waite, Peter Tait: A Remarkable Story (Stoke-sub-Hamden, UK: Milnford, 2005).

57 Wise, 161 and 224. This probably included Confederate government cotton.

58 Wharncliffe Manuscripts, Wharncliffe to Collie, 17 February 1866, item no. 86, Wharncliffe to Stringer, 9 April 1868, item no. 87, Wharncliffe to Spence, n.d., item no. 89. 
twenty-five percent as his reward.

Collie had convinced himself, his partners and investors that, in the event of victory, the United States would honour the Confederacy's bonds and foreign commitments. To some extent he was right. In a spirit of reconciliation, the United States government effectively closed its eyes to the offending acts of those who had made war upon it by extending an amnesty as a reward for their return to allegiance. Under the Abandoned and Captured Property Act of $1863,{ }^{59}$ the principal offenders in treasonable acts were granted a presidential pardon. Even British subjects, who by residence owed temporary allegiance to the United States, could be restored to the possession of their property. In early 1864, United States consuls were asked to report on any person who may have aided the rebellion by furnishing blockade runners or munitions of war. If, within two years of the rebellion ending, they had given no aid or comfort to the Confederate States, they could apply to the Court of Claims for compensation. Using article twelve of the Act as reference, Collie applied to recover the proceeds of the cotton stored at Savannah plus the value of that which had been burnt on the quay by order of General Sherman in December 1864. With the passage of time, the addition of other damages and considerable optimism, Collie's claim amounted to US\$4,415,905.34.

In March 1876, the liquidator declared the first dividend for Collie's creditors and, three months later, a second dividend of one shilling-and-three-pence in the pound. ${ }^{60}$

\section{Accounting for Debt}

The true extent of Alexander Collie \& Company's losses only became apparent in 1874 when the shareholder's allegations of 1866 became public. The company was still registered to trade as a commission merchant at 17 Leadenhall Street in the City. Little about its financial problems had been reported in the London business press since they were full of the national outcry over delays in Parliament to merchant shipping legislation sponsored by Samuel Plimsoll. However, on Independence Day in 1875, a headline in the New York Times announced several heavy failures in Britain caused by the suspension of Alexander Collie and Company, which owed some $£ 3$ million. ${ }^{61}$ The news spread rapidly and exposed many interesting sidelights on contemporary business practice. One merchant, Strachan and Company, declared assets of $£ 5,711$ against liabilities of $£ 96,938$, mainly on acceptances to Collie. Another claimed that cotton owned in a joint venture with Collie had been sold without his knowledge and in contravention of the trust on which it was held. Within two days, the London Gazette announced the first Bankruptcy Court meeting on a Proceedings for Liquidation by Arrangement for Alexander and William Collie.

A creditors meeting on 29 July 1875 in the City Terminus Hotel in Cannon Street

59 United States Abandoned and Captured Property Act, 12 Stat. 820 (1863).

60 London Gazette, March 1876. In 1871 Colley (sic) (47) living with wife Flora (30) sister Christine (45) daughter Beatrice (6) son Douglas (4)+14 servants at The Dales, Whitefield, Pilkington, Lancs (UK census).

61 The Times (New York), 4 July 1875. 
heard a statement on the current balance-sheet of the company by John Young, an accountant. He explained that, despite considerable difficulty in obtaining information and explanations from the Collies, he estimated that on 2 July 1875, Alexander Collie and Company had liabilities of $£ 1,889,758$ against realisable assets of only $£ 250,542$. The figures were approximate and subject to further investigation but included Collie's heavily mortgaged houses, Carolina cotton warrants worth $£ 38,500$, and stocks and shares. The stock of cotton in a Manchester warehouse had an unknowable value since no profit and loss account had been drawn up in the past decade. ${ }^{62}$ Other nominal assets were said to be worth between $£ 300,000$ and $£ 400,000$, but their realization was extremely doubtful. They included the pending claim for compensation for Collie's seized cotton, on which he was very sanguine since he felt the United States would put difficulties in the way of its repayment if the estate was placed in bankruptcy. ${ }^{63}$

With the deficiency of Alexander Collie and Company at more than $£ 1$ million out of a total liability of almost $£ 2$ million, Alexander and William Collie were adjudicated bankrupt on 8 September 1875. Creditors had expected the mansion at 12 Kensington Palace Gardens, which had cost $£ 25,000$ twelve years earlier, to realise about $£ 15,000$, but another ten years elapsed before it was occupied again. ${ }^{64}$ Alexander Collie had a second home in the suburbs, Dover House at Roehampton in Surrey, which he furnished with his art collection and for which he had drawn company funds of $£ 123,103$ during the previous decade. In December 1875, an Oxford Street auction house put his possessions up for sale, including paintings by John Phillip, a friend and executor, a full set of Scott's Waverley novels and a pair of Purdy guns. ${ }^{65}$

The failure of Alexander Collie and Company raised several important issues of interest to the mercantile community and led to calls by traders and bankers for changes in the way the City worked. Collie had not just been careless in unsound trading, or even driven by circumstances to take some questionable course in his business dealings. It was clear that he had remorselessly speculated with the money of bill brokers, bankers, depositors and clients, and recklessly breached the City's ethos of My Word, My Bond. He had abused the credit system and the Limited Liability Act, which had come into force in 1855 . This act had permitted investors to hold partly paid shares which allowed them to manipulate financial instruments and encouraged merchants to risk potentially crushing liabilities and lose larger sums of money when a business suddenly ran into difficulties. It had already happened when the merchants Overend, Gurney failed in 1868, and a financial catastrophe suddenly spread to many other trading companies. ${ }^{66}$

\section{Fraud}

Alexander and William Collie were arrested in Manchester on 20 July 1875 and

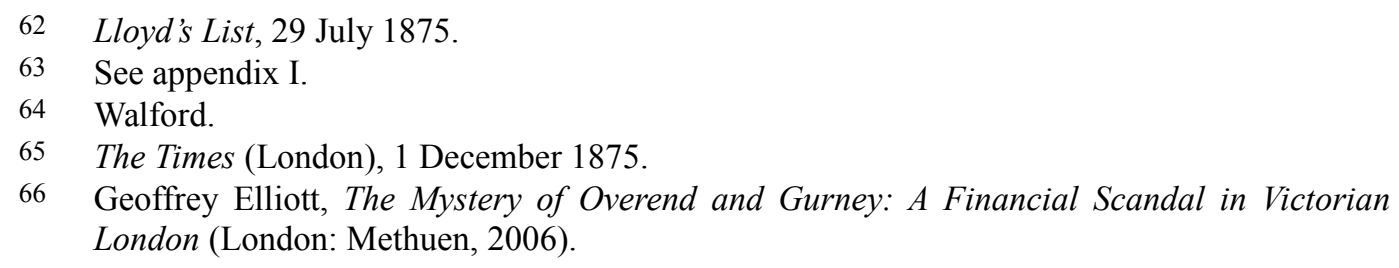


brought to London. The next day they appeared at the Guildhall police court on a warrant issued at the request of the London and Westminster Bank and, for first time, details of the charges of conspiracy to fraud were laid before them. Alexander was accused of obtaining large sums of money by falsely pretending, by the words "value received" followed by letters and other customary marks on the face of bills of exchange, that bales of cotton existed and had been assigned, in payment for which the bills were drawn. The drawer of a bill of exchange received cash by selling it to a bill broker or a joint stock bank but a large number of Collie's bills were no more than accommodation bills because they lacked the words "for goods." The Collies had sent the bills, accepted by various persons, to bill brokers who put them into circulation and several went to the London and Westminster Bank. When Alexander Collie and Company ceased trading in 1868, the bank held some half-million pounds worth on which, even after giving credit for what it could recover from the Collies' estate, its loss was up to $£ 300,000$. The bank claimed it only discounted the bills by a large amount because it believed from the marks on them that they were bona fide bills for commercial transactions that had been given for goods supplied. ${ }^{67}$ The Union Bank of Scotland additionally charged Alexander Collie with obtaining $£ 150,000$ on false pretences by personally making fraudulent statements to the manager. Each defendant posted a $£ 4,000$ surety, provided by both the Recorder of Manchester and a Manchester MP, and bail was set at $£ 2,000$ each. ${ }^{68}$

Proceedings against the Collie brothers commenced on 9 August 1875 at the Guildhall court before Sir Thomas White. Only William Collie surrendered to his bail and when Alexander Collie did not appear, his counsel said he had just learned that his client had not been at home for some days. The judge granted a warrant for Collie's immediate apprehension and ordered the $£ 4,000$ surety be forfeited "no matter how unfortunate that might be to those who had raised it." ${ }^{69}$ Since the prosecution did not intend to press William for the faults of Alexander, the latter should be present since his statements would be evidence against the former. Thus, rather than bringing William to court each week, it was proposed that he should not be called again until Alexander was arrested.

By not surrendering to his bail, Alexander Collie was charged with absconding and his counsel announced that in view of his client's absence, he had ceased to represent him. A reward of $£ 1,000$ was put up by the London and Westminster Bank for his arrest and a wanted notice was widely circulated in the press:

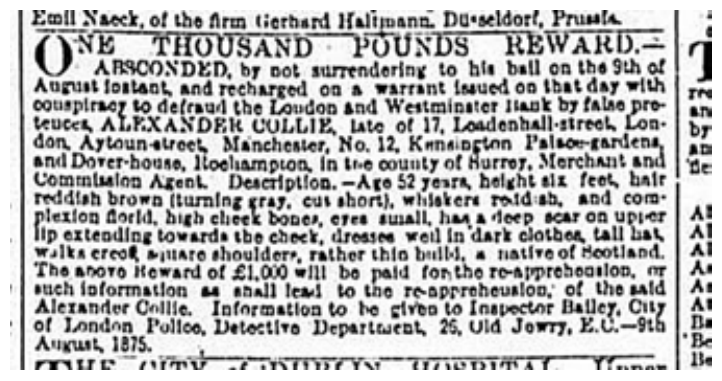

$£ 1,000$ Reward: Absconded by not surrendering to his bail on 9 August inst. Recharged on a warrant issued that day with a conspiracy to defraud the London \& Westminster Bank by false pretences, Alexander Collie of 17

67 See appendix IV.

68 Lloyd's List, 22 July 1875.

69 The Times (London), 10 August 1875. 
Leadenhall St., London, Aytoun St., Manchester, 12 Kensington Palace Gds. \& Dover House, Roehampton, Surrey, Merchant, Commission Agent. Description: age 52 years, height 6', hair reddish brown turning gray, cut short, whiskers reddish \& complexion florid, high cheekbones, eyes small, has a deep scar on upper lip extending towards cheek, dresses well in dark clothes, tall hat, walks erect, square shoulders, rather thin build, a native of Scotland. ${ }^{70}$

The London press had a field day. Not for many years had an event created such a sensation in the City and it quickly became the principal topic of conversation among traders. When a body was found in a thicket in Roehampton on 24 August, it was immediately suspected to be Collie. ${ }^{71}$

The Times called for no effort to be spared to capture Alexander Collie since other charges of a graver nature were likely to be instituted. The paper also commented that, while victims of financial fraud often had themselves to blame for their loss, Collie's deliberate and systematic fraud had been aggravated by an act of cowardice by leaving his brother to bear the brunt of the charges made against them. Having listened to the evidence against him, Alexander had not only realised he had no valid defence to the charges, but by disappearing he had admitted his guilt. Although William could not escape responsibility for the reckless trading of the company, his alleged complicity in the cases of fraud was another question. In Manchester, he had taken an independent course in running the office, whereas the offences were committed in London. ${ }^{72}$ The Times was evidently not aware of William's time in Wilmington.

On 7 September 1875, William Collie surrendered his bail but in the continued absence of his brother, the judge deferred the case until the end of the year. ${ }^{73}$ At a court hearing on 13 January 1876, the first mention of Alexander Collie being "out of the country" was made. ${ }^{74}$ The court, in accepting the separate nature of the transactions in which the brothers allegedly shared, adjourned William's case sine die.

\section{Compensation}

A treaty signed between the United States and Britain on 8 May 1871 set up a Mixed Commission at Liverpool in March 1872 to hear claims from British-born merchants who had resided in Britain between April 1861 and May $1865 .^{75}$ Collie had immediately sought compensation for his cotton seized at Savannah and the Commission found in his favour. It awarded him $£ 300,000$, subject to legal charges and expenses of $£ 190,000$, out of which about $£ 100,000$ would belong to the United States. In 1876, the United States government successfully appealed on the grounds that although Collie was

70 Ibid.

71 The Times (London), 24 August 1875. The body was later identified as that of Robert Grant, a Union Bank clerk suffering from alcoholism and depression. Ibid.

73 The Times (London), 9 September 1875.

74 Ibid., 13 January 1876.

75 Kew, England, The National Archives (TNA), FO 305/52-375 and 52-1376, Treaty United States and Great Britain, 8 May 1871. 
British-born and lived in Britain during the relevant period, he had, as a non-resident alien, engaged in loading and sending steamships to run the naval blockade of the states that were then in rebellion against the United States. These ships took back large quantities of cotton from ports in or around the rebelling states in payment for the munitions of war and other items that Collie had willingly provided.

Collie was also not covered by the United States Abandoned or Captured Property $\mathrm{Act}^{76}$ because at no time during the war had he been in the United States, therefore any of his cotton found within Confederate territory was legitimately subject to capture by the forces of the United States. Collie's trustee in bankruptcy, John Young, responded with a formal application to the United States Court of Claims under this Act on the grounds of newly discovered evidence. The court also dismissed this action because it was beyond doubt that Collie had voluntarily given aid and comfort to the rebellion and his gift to Colonel Lamb of the Whitworth field cannon and shot alone excluded him from the act. ${ }^{77}$

In the October term of 1877, the United States Supreme Court heard Young's appeal against the judgement of the Court of Claims. ${ }^{78}$ The judges found that presidential pardons granted after the end of the Civil War for offences against United States law were intended to relieve the owner of captured property from the need to prove that he did not give aid and comfort to the rebellion. In other words, the pardon was the equivalent to proof of his unbroken loyalty. Yet Collie, by reason of his hostile acts as an enemy, was not a traitor nor was he an offender in a criminal sense as he had committed no crime against the laws of the United States. If there was no offence, there could be no reprieve and Collie could not be included in the pardons granted by the president. He had, though, as an agent for North Carolina, done as much as any private person to aid the Confederacy as illustrated by his gift of the Whitworth cannon.

Collie's property within enemy territory was enemy property and the title to his cotton rested with the United States to do with as it pleased. Property captured during the war was not taken in punishment for the treason of the owner but because it had become involved in the war. Its removal from the enemy was to lessen their warlike power because of its character and not due to its ownership. Without the provisions of the Abandoned and Captured Property Act, the title to all captured property and its proceeds passed absolutely to the United States. By that act, the privilege of suing for the proceeds was granted only to owners who could show they had not given aid or comfort to the rebellion. Since this was a reward for loyalty and not a punishment for disloyalty, Collie had not been deprived of any right he ever had and therefore could not sue the United States in such a claim. He was asking for a privilege now granted to those who had never aided the rebellion, or who, owing allegiance to the United States, had been pardoned for their offence of disloyalty. What Collie wanted was the grant of a new right. If his property had been captured by the United States in circumstances that entitled him to its

76 United States Abandoned and Captured Property Act.

77 Young v. United States. 12 Ct. Cl 648 December Term (1876); see Appendix III.

78 Young v. United States. U.S. Supreme Court 97 U.S. 39 (1877) Appeal; see Appendix IV. 
restoration, the law gave him the right to claim through his own government. It would then be dealt with by diplomatic representations and that was the only right Collie had when his cotton was taken. Although the President, by his pardon, might have restored lost rights, it had never been supposed that he could grant new ones.

The Supreme Court upheld the original decision by the Court of Claims to reject Young's claim for compensation, but for a different reason. While it agreed that a Presidential pardon furnished conclusive evidence that the offending acts against the government never existed, it was for the legislative department, not the judicial, to say whether the same rule applied in cases where there can be no pardon. A pardon of an offence removes the offending act out of sight; but, if there is no offence in the eye of the law, there can be no pardon. Consequently, the acts which are not extinguished by a pardon remain to confront the actor. In a last throw of the legal dice, John Young wrote to the foreign secretary, Earl Granville on 3 August 1882, requesting him to take the matter up with the United States. Nine months later, on 24 April 1883, the Foreign Office replied that the government could take no further action and the case was now closed. ${ }^{79}$

\section{Postscript}

For a decade and a half, the name of Alexander Collie was hardly mentioned in Britain. On 5 July 1878, the Court of Appeal in London reported the decision of the Supreme Court of the Judiciary to grant an appeal on the matter of Alexander and William Collie's bankruptcy to the House of Lords ${ }^{80}$ The Trustees reported on 23 May 1881 that, despite rumours that Alexander Collie had made a disposition of his property in favour of his wife and gone to Spain where there was no extradition treaty, ${ }^{81}$ the whole of his property had been realised. ${ }^{82}$ In December 1885, the High Court of Justice announced a fifth dividend for his creditors of $2 \frac{1}{4}$ pence in the pound, and in June 1889 , fourteen years after Collie's bankruptcy, the sixth and final dividend was declared but it amounted to only $21 / 32$ nds of one penny in the pound. A total dividend of 3 shillings and $31 / 16^{\text {th }}$ pence in the pound had been paid to creditors - about 16 percent - and it was no longer necessary to protract the bankruptcy. There had been no entry for the Collie family in the 1881 census but, in 1901, Flora J. Collie, aged 58 and a widow, was living on her own means and with three servants at The Belfry House, Rousham, Oxfordshire. She died in 1903 at Mutford in Suffolk, although a notice in the London Gazette in the following year that invited claims against her estate described her as "late of the Old House, Swanbourne Winslow in Buckinghamshire and formerly of Rousham Rectory near Oxford." 83

It seemed that Alexander Collie had successfully escaped the law but, in doing

79

80

81

82

83

TNA, FO 5/186, Memorial record of the bankruptcy and claim of Young against the U.S.

The Times (London), 17 July 1878.

Obituary, The Daily News (New York), 29 November 1895.

There was no entry for the Collie family in the 1881 UK Census.

London Gazette, 25 March 1904. In 1891 Flora J. Collie (48) described as married, head of house, living on own means with Flora Beatrice, grandson Richard and 2 servants at Manor House, Fyfield, Berks. Census. 
so, suffered a life-long exile. At first there were rumours in the City that he had been lost at sea, or gone to South America, or been seen in America employed as a stationmaster in an unnamed town. Not surprisingly, it was a newspaper obituary in the town where Collie was born that gave the fullest account of this period. ${ }^{84}$ After he failed to appear at the Guildhall Police court in 1875, Collie went to the United States where he still had friends and business connections in the former Confederacy. It may be that he went to pursue the restitution of his cotton in the United States Courts, so that while his trustee was appealing for compensation, partly on the grounds that he never set foot in America, he was secretly living in Virginia. He may also have known that his old friend, Colonel William Lamb, to whom he had given the crucial Whitworth gun in 1864, had returned to Norfolk, Virginia, where he was mayor between 1880 and 1886.

Alexander Collie was eventually recognized at Greenbrier White Sulphur Springs in West Virginia by a fellow Scot, George Peterkin Grant. Now calling himself George Macneill, the combination of his father's given name and his wife's maiden name, Collie's knowledge of finance had led to an association with Colonel Parsons and General Butler in running the Richmond - Allegheny railroad. Initially, with speculation and stock manipulation rife in the state, Collie was successful and grew prosperous again, but misfortune followed. By the early 1890s, he was comparatively penniless and living alone in New York in a Harlem apartment "in conditions that sapped his strong constitution and he became an invalid." 85

A two-line notice in the Times on 28 November 1895 announced Alexander Collie's death: "Collie, on 23 November in New York, Alexander Collie late of 12 Kensington Palace Gardens."

The following day a Times editorial remarked that a quarter of a century earlier Alexander Collie had "carried out a notable system of fraudulent trading, the collapse of which has left results not yet forgotten in the City." 86 In America, his death was announced under a headline "once millionaire died almost a pauper." 87 A Maryland newspaper reported that a noted blockade runner in the Civil War, who established quarters at Wilmington and some years earlier "could have drawn his check for millions of dollars and ... was known in almost every European capital" ${ }^{88}$ had died impoverished a few days earlier. It transpired that Collie had been turned out of his flat in Harlem and had been staying at the Colonial Hotel on $125^{\text {th }}$ Street where he was found by friends. A few men were the only mourners at his interment at the Woodlawn cemetery and the funeral expenses were paid by Richard Lamb, a well-known inventor and eldest son of Colonel William Lamb. ${ }^{89}$

84 Obituary, The Weekly Journal (Aberdeen), 30 November 1895.

85 Ibid., 31 December 1895.

86 The Times (London), 29 November 1895.

87 Obituary, Daily Tribune (New York), 10 December 1895.

88 Obituary, The News (Frederick, MD) 13 December 1895.

89 Obituary, The Newsletter (Belfast), 13 December 1895. 


\section{Conclusion}

Trading with the Confederacy during the Civil War had many ups and downs. As in old smuggling times, it attracted the type of speculator who was willing to sacrifice one cargo in three. With reasonable luck, his small, shallow and fast vessel would find favourable winds and coastal sea-fogs to hide in. If successful, there would be a ready demand for his goods and, provided the broker only robbed him in moderation, profits would be enormous. On the other hand, a captured blockade-running vessel and its cargo could be appropriated and the captain and crew detained indefinitely to appear as witnesses in an unfriendly prize-court. ${ }^{90}$

If looked at separately, most of Alexander Collie's trading appeared legitimate but, when examined in detail, the conflicts of interest become clear. As J. M. Barrie noted, there are few more impressive sights in the world than a Scotsman on the make. ${ }^{91}$ Collie's impressive plan was to have a finger in every pie and not depend on decisions made by boards of directors, partners or committees. He alone contracted the best available vessels, bought them for his own company with the money of other people, he loaded them with his own cargoes paid for with profits from marketing Confederate cotton-bonds in Britain and the commission he earned on each deal. He even raised the war-risks insurance for his ships and cargoes by public subscription. In other words, he remorselessly speculated with the money of business partners, depositors, bill brokers and bankers and the public. Yet they all seemed reluctant to complain when they discovered they had been cheated. Collie's financial crisis was not just the result of unsound trading but rather because he had deluded himself about the outcome of the Civil War and it was largely the defeat of the Confederacy that led to his bankruptcy and set him on the course to fraud.

Collie's demise changed the way the City of London carried on business. Eventually, the Limited Liability Act was amended to restrict the potential loss of large sums of money when companies failed. Bill brokers realised that the completion of the Suez Canal in 1869 meant there was no longer a need to draw bills of exchange valid for six months since the voyage from China now took six weeks and India only one month. The merchants, who were Collie's sureties, were justly fined by forfeiting their recognizance and the legal profession sought better means of ensuring detention than the ridiculed system of bail. His final epitaph was written by United States Supreme Court when it found that by giving aid and comfort to the enemies of the United States Collie was not entitled to the privileges of a presidential pardon. However, it implied that foreigners might be as entitled to the privileges of the Abandoned Property Act as the pardoned enemies themselves, but that was for Congress to determine and not the court. If Alexander Collie had remained in Britain or his powerful friends in the government had pursued his case or petitioned the United States Congress, his story could have ended differently.

90 Anon., "Adventures of a Blockade Runner," The Times (London), 6 September 1892.

91 J. M. Barrie, What Every Woman Knows: A Comedy in Four Acts (1908). 


\section{Appendix I}

\section{$\underline{\text { Messrs Collie's Creditors }}$}

Mr Young (of the firm Turquand, Youngs \& Co., accountants) read an "approximate" statement on the affairs of Messrs Collie as they stood on 2 July 1875 :

Creditors unsecured were due $£ 90,0277 \mathrm{~s} 2 \mathrm{~d}$ which was principally for goods sold and delivered in the regular course of the Manchester business. Creditors' balances, subject to payment of their acceptances, $£ 1,274,2925 \mathrm{~s} 5 \mathrm{~d}$; creditors partly secured, claim $£ 42,788 \mathrm{8s}$; security $£ 22,2482 \mathrm{~s} 10 \mathrm{~d}$, leaving $£ 20,5405 \mathrm{~s} 2 \mathrm{~d}$ to rank in the estimate; creditors fully secured, security $£ 197,3863 \mathrm{~S} 11 \mathrm{~d}$; claim, $£ 165,0363 \mathrm{~s} 11 \mathrm{~d}$, leaving an estimated surplus of $£ 32,350$. These securities would require time to realise, and [Young] could not say that the amount reckoned as surplus would be realised.

The next items were $£ 927$ 9s $11 \mathrm{~d}$ to creditors for rents, rates and salaries, and liabilities per list, $£ 39,41814 \mathrm{~s} 7 \mathrm{~d}$. These were liabilities for engagements entered into by Messrs Collie. The liabilities on the bills receivable were estimated to rank at $£ 480,84919$ s $5 \mathrm{~d}$, but deducting cash and all other securities in the hands of holders of the bills - $£ 16,27010 \mathrm{~s}$ $11 \mathrm{~d}$ - the amount was reduced to $£ 464,5798 \mathrm{~s} 6 \mathrm{~d}$, the total estimated liabilities amounting to $£ 1,889,78310$ s $9 \mathrm{~d}$.

On the credit side of the statement: cash at bankers and retained against bills discounted was $£ 11,40610$ s $11 \mathrm{~d}$, cash in hand $£ 15,29518 \mathrm{~s} 10 \mathrm{~d}$, and estimated to realise $£ 7,500$. Debtors were good to the amount of $£ 12,775$ $12 \mathrm{~s} 7 \mathrm{~d}$; stocks in warehouses etc at Manchester were estimated at $£ 48,60718 \mathrm{~s} 3 \mathrm{~d}$, making a deduction of 15 percent from the cost price, although so far they had had no such reduction. Stocks and shares and sundry assets were estimated to realise $£ 30,510$, and Young had little doubt that this amount would be realised.

The freehold premises in Aytoun St., Manchester were estimated to realise $£ 75,000$ after payment of the balance of the purchase money. On the separate estates, the estimated surplus for A. Collie was $£ 60,000$, including house, furniture, pictures etc., and W. Collie at $£ 15,000$. Young considered that the estimated available assets amounting to $£ 250,542$ would produce something like $2 \mathrm{~s} 6 \mathrm{~d}$ in the pound.

Other assets requiring time to realise were: estimated surplus from creditors fully secured, to which he had already referred: $£ 32,350$; bad debts, amounting to $£ 223,198$, were not expected to realise more than $£ 10,000$; sundries, expected to realise $£ 71,000$, and Carolina cotton 
warrants, $£ 38,500$.

... On Collie's claim against the United States Government, judgement was recovered against that Government, subject to appeal and subject to law charges and expenses of $£ 190,000$, out of which it was estimated $£ 100,000$ would belong to the State and the rest to the venturers. Other amounts to be recovered were estimated at $£ 300,000$ against a claim for cotton burnt during the American Civil War... Thus the available assets were $£ 250,5027 \mathrm{~s} 11 \mathrm{~d}$, against liabilities of $£ 1,889,78510 \mathrm{~s} 9 \mathrm{~d} .{ }^{92}$

\section{Appendix II}

\section{The Charges Against Messrs Collie}

It is alleged that Alexander and William Collie conspired together to draw bills which were nothing but accommodation bills, and they represented that they were trade bills given for goods sold, and bearing on the face of them certain marks and numbers purporting to refer to the bales of goods and the accounts in the ledger. The bills which purported to be for value received had on its face "for value received" and certain marks which purported to refer to the description of goods that the bill was given for. A large number of those bills had been negotiated, and although a great number of the bills had not the words "for goods" on them, they had certain marks on them which were equivalent, for they had those marks which purported to refer to accounts of goods delivered. The defendants sent bills, accepted by various persons, to bill brokers, and by that means put them into circulation. It was well known that the bill brokers could not discount those bills with their own money, and several went to the London and Westminster Bank. In May or June they failed, and their liabilities were about $£ 3,000,000$ but of that sum there were from $£ 1,500,000$ to $£ 1,750,000$ worth of those bills in circulation. The London and Westminster Bank had about $£ 500,000$ worth of those bills and after giving credit for all that they could get from the estate they would be at a loss of between $£ 200,000$ and $£ 300,000$. It was obvious that the bank would not have discounted bills to that large amount if they had not believed that those bills were given for goods that had been supplied, and that the marks and numbers on the face of those bills referred to those goods.

On the examination of the defendant's books, which were placed in the hands of Mr John Young, of the firm Turquand, Young \& Co., accountants, it was found that those bills were not genuine trade bills drawn for goods sold, but accommodation bills, and that there were no such goods sold, and no such accounts in the ledger as those indicated by the marks on the face of the bills, and also that the persons accepting the

92 The Times (London), 29 July 1875. 
bills had no goods accounts with the defendants. The London and Westminster Bank believed they had a responsible drawer and acceptor, and upon that assumption they would have discounted to a reasonable amount, but they never would have discounted to such an amount if they had not believed, from the marks on the face of the bills, that they were bona fide bills for commercial transactions. By examining the books they found that there were goods to the amount of $£ 63,000$, or from that to $£ 100,000$, which were all that represented the million and a half or million and three quarters for which bills were in the hands of the bank and other persons. ${ }^{93}$

\section{Appendix III}

\section{The U.S. Court of Claims Decision}

Young v. United States, 12 Ct. Cl. 648, December Term (1876)

The twelfth section of the Abandoned or Captured Property Act (12 Stat. 765 ) imposes the following limitation on a person claiming to have been the owner of abandoned or captured property. Provided, however, that in order to authorise the said court to render a judgement in favour of any claimant, if a citizen of the United States, it shall be set forth in the petition that the claimant, and the original and every prior owner thereof where the claim has been assigned, has at all times borne true allegiance to the Government of the United States, and, whether a citizen or not, that he has not in any way voluntarily aided, abetted, or given encouragement to rebellion against the said government, which allegations may be traversed by the government: and if on the trial such issue shall be decided against the claimant, his petition shall be dismissed...

The real question in the case, then, is, whether Alexander Collie, a nonresident alien, who voluntarily gave aid and comfort to the rebellion, is entitled to prefer his claim here for the proceeds of his cotton. Beyond doubt, the terms of the act exclude him, just as it did all men who had given aid and comfort to the rebellion... Equally beyond controversy, Alexander Collie's sending munitions of war from the country of his domicile to the rebel States was not an act which subjected him to punishment under the laws of the United States. The worst that could befall him was the capture in transitu of those munitions.

Hence it follows, as a clear, inevitable conclusion, that he was not the subject of amnesty, and therefore can claim nothing through it. 


\section{Appendix IV}

\section{The U.S. Supreme Court Decision}

Young v. United States, 97 U.S. 39 October Term (1877)

The court has decided, in reference to the Abandoned and Captured Property Act, that a [Presidential] pardon relieves the owner of captured property from the necessity of proving he did not give aid and comfort to the rebellion, because the pardon is equivalent to actual proof of his unbroken loyalty... In a spirit of conciliation, the nation has pardoned those who, owing it allegiance, have made war upon it, and closed the eyes of the government to their offending acts. It was a bounty extended to them for their return to allegiance.

Collie, though by reason of his hostile acts an enemy, was not a traitor. He was no offender, in a criminal sense. He had committed no crime against the laws of the United States or the laws of nations, and consequently he was not, and could not be, included in the pardon granted by the President in his proclamation. His offending acts, therefore, have not been shut out, and he and his representatives remain subject to all his original disabilities under the statute.

Property captured during the war was not taken by way of punishment for the treason of the owner... it was because it had become involved in the war, and its removal from the enemy was necessary in order to lessen their warlike power. It was not taken because of its ownership, but because of its character. But for the provisions of the abandoned and Captured Property Act, the title to and the proceeds of all captured property would have passed absolutely to the United States. By that act, however, the privilege of suing for the proceeds in the treasury was granted to such owners as could show they had not given aid or comfort to the rebellion. This was a reward for loyalty, not a punishment for disloyalty. Collie has been deprived of no right he ever had...

What he asks is not a restoration to a right which he once had, and by his misconduct has lost, but the grant of a privilege which those who have never given aid or comfort to the rebellion, or who, owing allegiance to the United States, have been pardoned for their offence of disloyalty, now possess...

All he had to do was to induce his government to assume the responsibility of making his claim, and then the matter would be "prosecuted as one nation proceeds against another."... This was the only right Collie had when his cotton was taken, and the United States have never consented to grant him any other. While the President, by his pardon, may restore lost rights, it has never been supposed that in such a way he can grant new ones. 
It may be that foreigners who have given aid and comfort to the enemies of the United States are in equity as much entitled to the privileges of the act as the pardoned enemies themselves: but that is for Congress to determine, and not for us. We have decided that the pardon closes the eyes of the courts to the offending acts, or, perhaps more properly, furnishes conclusive evidence that they never existed as against the government. It is with the legislative department of the government, not the judicial, to say whether the same rule shall be applied in cases where there can be no pardon by the President. A pardon of an offence removes the offending act out of sight; but, if there is no offence in the eye of the law, there can be no pardon. Consequently, the acts which are not extinguished by a pardon remain to confront the actor. 